\title{
PENDAMPINGAN BELAJAR FISIKA BERBASIS SMART SOLUTION DENGAN REAL WORLD PROBLEM BAGI SISWA SMP DI DESA MALANUZA KECAMATAN GOLEWA
}

\author{
Maria Yuliana Kua ${ }^{1}$, Ni Wayan Suparmi ${ }^{2)}$, Ni Wayan Prawita Aryani ${ }^{3)}$ \\ Josep Marsianus Rewo ${ }^{4)}$ \\ 1,2,3,4)Program Studi Pendidikan IPA, \\ 1,2,3,4)Sekolah Tinggi Keguruan dan IImu Pendidikan Citra Bakti \\ 1)yulianakua03@gmail.com, ${ }^{2}$ wayansuparmi458@gmail.com, ${ }^{3)}$ witaloveforus@gmail.com, \\ 4) josmarrewosiu@gmail.com
}

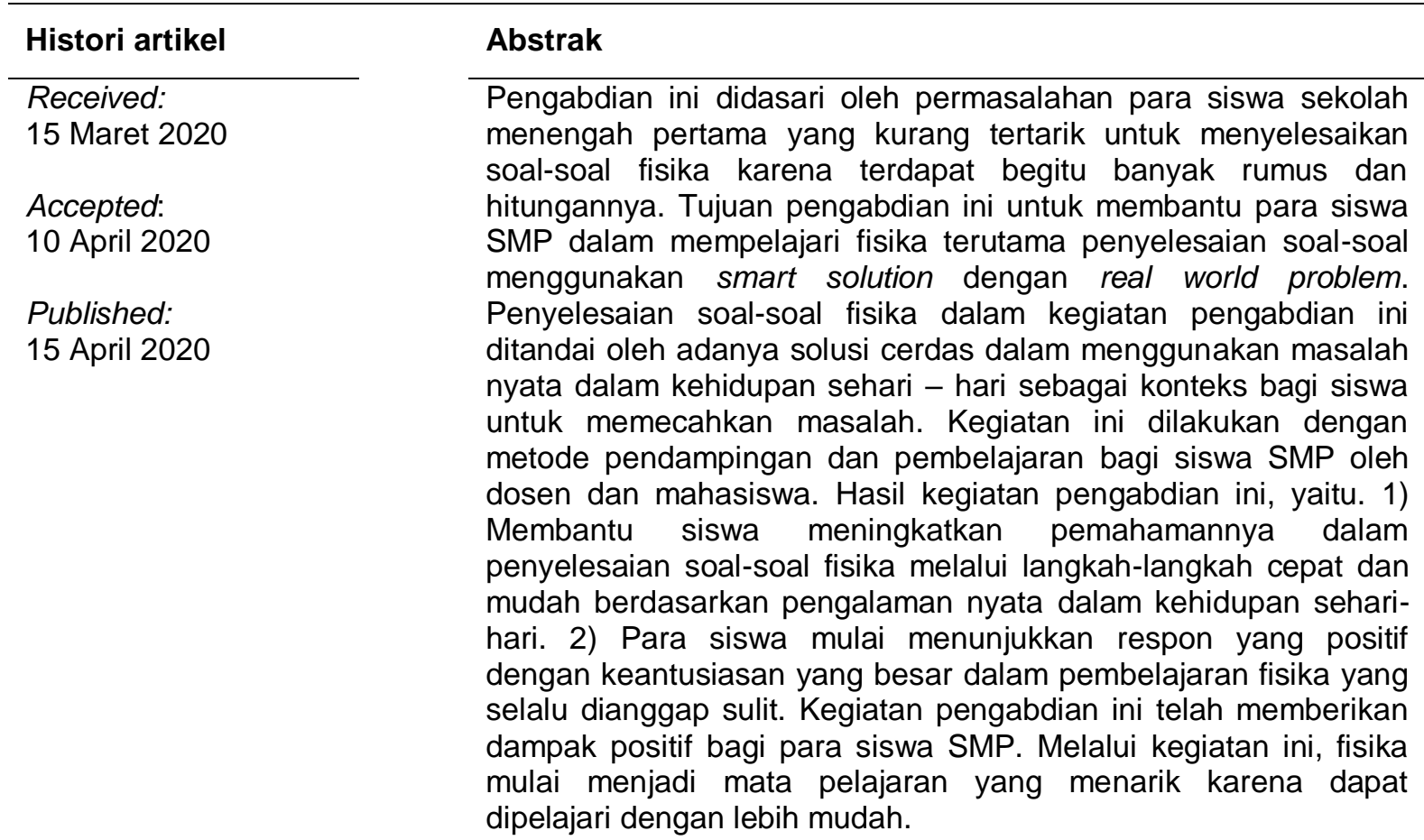

Kata-kata Kunci: real world problem, smart solution 
Abstract. This community service was started from reality lived by junior high school students who found that solving problems on Physics was less interesting since it required a lot of formula and calculation. It would help them in learning Physics especially solving problems through smart solution using real world problem. It contained smart solution using samples in daily life for reference to solve the problem. The activity was conducted through mentoring and learning for junior high school students by lecturers and university students. This community service resulted in 1). Improvement of student's comprehency in solving Physics problems through quick and easy steps using real life situations 2). Positive response from student by showing enthusiasm in learning Physics. The community service gave positive impacts to junior high school students. Through the activity, Physics became one interesting subject to learn with easy.

Keywords: real world problem, smart solution

\section{PENDAHULUAN}

IImu pengetahuan pada dasarnya dikembangkan secara khusus melalui pendidikan yang ditempuh pada jalur formal di bangku sekolah. Kegiatan pembelajaran dalam keseluruhan proses pendidikan di sekolah merupakan kegiatan yang paling pokok. Hussain \& Shakoor (2011) menjelaskan dalam penelitiannya bahwa hal terpenting dari rangkaian proses pembelajaran tersebut adalah untuk mengoptimalkan kemampuan siswa dalam membuat keputusan terhadap berbagai situasi yang dihadapi. Siswa yang melakukan proses belajar akan mengalami perubahan baik dalam hal pengetahuan, keterampilan, nilai, maupun sikap. Pengetahuan yang dipelajari siswa di sekolah meliputi berbagai bidang disiplin ilmu dan salah satunya adalah mata pelajaran fisika.

Nchunga \& Kira (2016) dalam penelitiannya menguraikan bahwa fisika merupakan bagian terpenting dari ilmu pengetahuan dan teknologi karena banyak alat-alat kebutuhan manusia yang dikembangkan berdasarkan konsep fisika. Fisika merupakan salah satu cabang ilmu dalam rumpun sains yang dibelajarkan kepada siswa dalam proses pembelajaran di sekolah. Mengacu pada Permendiknas No. 22 Tahun 2006, salah satu tujuan pembelajaran fisika adalah mengembangkan kemampuan bernalar siswa dalam berpikir analisis secara induktif maupun deduktif dengan menggunakan konsep dan prinsip fisika untuk menjelaskan berbagai peristiwa alam dan menyelesaikan masalah baik secara kualitatif maupun kuantitatif. Bila dicermati, hal ini mengandung makna bahwa proses pembelajaran yang dilakukan harus memberi kesempatan secara luas kepada siswa untuk mengembangkan kemampuan berpikir. Pengetahuan yang berupa konsep-konsep atau hukum harus diperoleh atau dibangun melalui serangkaian proses sains, salah satunya melalui kemampuan berpikir siswa.

Hasil penelitian Nchunga \& Kira (2016) menjelaskan pula bahwa dalam kelompok sains, fisika termasuk mata pelajaran yang sulit dihadapi siswa. Hal inilah yang menjadi alasan mengapa siswa selalu mendapatkan hasil belajar yang rendah. Lebih lanjut, penelitian Johan (2012) menunjukkan bahwa salah satu masalah dalam pembelajaran yaitu proses yang dilakukan belum merangsang kemampuan siswa untuk merumuskan masalah dan memilih pemecahan masalah. Pembelajaran masih bersifat teacher center 
dan bukan student center. Akibatnya penguasaan materi menjadi dangkal karena siswa kurang didorong untuk mengkonstruksi sendiri suatu konsep dalam pikirannya. Hal ini mengimplikasikan bahwa untuk dapat mendorong siswa belajar dengan baik dan dengan situasi yang menarik, perlu dilakukan proses pembelajaran dengan cara yang baik pula.

Sehubungan dengan proses pembelajaran fisika, hasil penelitian Warimun (2012) menunjukkan bahwa pengetahuan tentang fisika bukanlah hal yang sulit untuk diterima oleh siswa. Kesulitannya terletak pada pengaplikasian pengetahuan tersebut secara fleksibel dalam memecahkan masalah. Pembelajaran yang berbasis pada pemecahan masalah termasuk dalam pembelajaran kontekstual yang dapat membangun proses yang aktif di mana siswa menjadi penerima informasi aktif, serta lebih menekankan pada program pendidikan dari mengajar menjadi pembelajaran. Hal ini menunjukkan bahwa ketika memecahkan masalah fisika, siswa dituntut untuk dapat menganalisis data dan masalah, menjelaskan fenomena, mencari informasi tambahan, memilih model dan cara penyelesaian masalah, memilih persamaan yang tepat, menyelesaikan masalah dan, menginterpretasikan serta menyajikan hasil. Situasi masalah yang disajikan dalam pembelajaran merupakan suatu stimulus yang dapat mendorong potensi kreativitas siswa terutama dalam hal pemecahan masalah.

Oleh karena itu, sangat penting untuk dilakukan proses pembelajaran dengan menggunakan konsep pemecahan masalah yang membantu siswa dalam memahami fisika itu sendiri yang seringkali menjadi momok dalam rangkaian proses belajar siswa. Materimateri fisika yang dipenuhi deretan persamaan dan angka-angka membuat siswa merasa kesulitan untuk memahaminya. Smart solution adalah metode belajar yang membantu siswa dalam mempercepat penyelesaian soal-soal menggunakan cara dan rumus yang mudah diingat. Secara terminologis, smart solution berarti solusi cerdas. Penerapan metode ini dalam pembelajaran fisika diharapkan dapat membantu siswa dalam penyelesaian soal-soal fisika yang selalu dianggap sulit untuk dikerjakan.

Lebih dari itu, Docktor \& Mestre (2014) dalam penelitiannya menjelaskan mengenai salah satu alternatif dalam pemecahan masalah yaitu real world problem. Kua, et al (2015) menjelaskan bahwa "Real world problems is one of the alternative solutions which in this case is used as away to introduce the students to the real problems in understanding the concept of physics". Penerapan metode smart solution dengan real world problem ditandai oleh adanya solusi cerdas dalam penyelesaian soal menggunakan masalah nyata sebagai konteks bagi siswa untuk belajar kritis, memecahkan masalah serta memperoleh pengetahuan. Lebih lanjut Kua (2018) menjelaskan bahwa proses pembelajaran dengan menghadirkan permasalahan nyata dalam kehidupan sehari-hari akan membantu siswa dalam mengembangkan dan menerapkan kemampuan pemecahan masalah dalam lingkungan siswa baik dalam keterampilan belajar sendiri atau kerjasama kelompok. Jika 
siswa dapat melihat adanya keterkaitan antara kehidupan mereka dan materi yang dipelajari, mereka akan lebih tertarik terhadap pembelajaran yang berlangsung.

Berdasarkan hasil observasi dan wawancara dengan beberapa siswa sekolah menengah pertama di SMP Negeri 4 Golewa dan SMP Citra Bakti, mata pelajaran fisika merupakan salah satu mata pelajaran selain matematika yang terasa sangat sulit untuk dipahami karena terdapat banyak rumus dan hitungan yang mematahkan semangat untuk belajar. Konsep-konsep pembelajaran yang disertai rumus, simbol, dan satuan membuat siswa kurang tertarik untuk mempelajarinya dalam waktu yang lebih lama. Hal ini jelas mempengaruhi waktu belajar fisika siswa. Pada akhirnya, siswa hanya belajar fisika di sekolah tanpa merasa ingin tahu untuk mempelajarinya lebih lanjut di luar jam sekolah, selain dengan terpaksa mengerjakan tugas rumah yang tanpa bisa dipungkiri dilakukan dengan cara menyalin pekerjaan teman lain. Selain itu, banyak di antara para siswa yang masih bertanya-tanya apa perlunya mempelajari fisika. Permasalahan seperti diuraikan ini jelas timbul karena para siswa kurang diberikan permasalahan-permasalahan yang berbasis pada kehidupan nyata sehari-hari.

Menyikapi persoalan yang sering dialami siswa-siswi SMP terutama di desa Malanuza dalam memahami materi fisika, maka dipandang perlu untuk dilakukannya proses pendampingan belajar fisika berbasis smart solution dengan real world problem. Melalui program ini diharapkan: 1) rumus-rumus fisika yang dikembangkan dalam smart solution dapat dengan mudah diterapkan untuk menyelesaikan soal-soal sehingga dapat meningkatkan pemahaman siswa terhadap materi fisika yang dipelajari; 2) keterkaitan antara kehidupan siswa dan materi yang dipelajari, dapat mendorong siswa untuk lebih bersemangat terhadap proses pembelajaran yang berlangsung sehingga dapat menumbuhkan kecintaan siswa akan fisika. Dengan demikian, pelaksanaan program ini dapat memberikan jawaban terhadap permasalahan para siswa SMP yang mengalami kesulitan dalam mempelajari fisika.

\section{METODE PELAKSANAAN}

Khalayak sasaran kegiatan pengabdian masyarakat ini adalah siswa - siswi SMP di desa Malanuza yaitu para siswa SMPN 4 Golewa dan SMP Citra Bakti. Malanuza merupakan salah satu desa yang terdapat di kecamatan Golewa, kabupaten Ngada, provinsi Nusa Tenggara Timur. Desa ini merupakan salah satu dari 21 desa dan kelurahan yang berada di kecamatan Golewa.

Metode yang digunakan dalam upaya meningkatkan semangat belajar fisika siswa SMP di desa Malanuza adalah melalui pendampingan belajar oleh para dosen program studi pendidikan IPA dengan melibatkan mahasiswa sebanyak 10 orang agar proses belajar 
menjadi efektif dan para siswa dapat didampingi secara langsung untuk mengatasi kesulitan belajar yang dialami.

Langkah-langkah kegiatannya adalah:

1. Membangun komunikasi dengan pihak sekolah agar diperkenankan memberikan kesempatan kepada para dosen dan mahasiswa untuk menggunakan waktu siswa di luar jam sekolah dalam pelaksanaan program pengabdian ini.

2. Mendata siswa kelas IX dari kedua SMP tersebut

3. Melakukan pretest sebagai upaya untuk dapat membagi kelompok yang heterogen bagi para siswa tersebut.

4. Setelah mendapat hasil pretest, para siswa kemudian dibagi dalam beberapa kelompok berdasarkan hasil pretest sesuai jenjang kelas dengan tingkat kemampuan yang heterogen.

5. Masing-masing kelompok belajar akan diatur jadwal oleh dosen dan mahasiswa pendamping untuk melakukan tatap muka.

6. Proses yang terjadi adalah sebagai berikut: pada pertemuan 1-2, siswa akan melakukan diskusi untuk menyelesaikan masalah dan soal-soal yang disajikan oleh pendamping menggunakan cara yang biasa digunakan oleh siswa dalam penyelesaian soal. Pada pertemuan 3-7, pendamping akan mengarahkan siswa dalam penyelesaian soal menggunakan smart solution dengan real world problem. Selanjutnya, pada pertemuan 8, siswa akan diberikan posttest untuk penyelesaian soal dan masalah-masalah fisika dengan harapan bentuk penyelesaian yang diberikan telah menggunakan metode smart solution.

7. Dengan demikian, masing-masing kelompok belajar akan mendapatkan kesempatan belajar minimal 6 kali tatap muka yang didampingi oleh dosen dan mahasiswa.

8. Selain itu pula, akan dilakukan wawancara kepada beberapa orang siswa SMP peserta kegiatan pengabdian ini untuk memperoleh informasi mengenai pengaruh metode smart solution dengan real world problem terhadap proses pemecahan masalah fisika dan minat siswa terhadap pembelajaran fisika.

\section{HASIL DAN PEMBAHASAN}

\section{Hasil}

Kegiatan pendampingan belajar fisika berbasis smart solution dengan real world problem dilaksanakan di SMPN 4 Golewa dan SMP Citra Bakti setelah melakukan koordinasi dengan kepala sekolah dan guru IPA. Kegiatan penadampingan ini diberikan kepada siswasiswi kelas VIII oleh dosen dan mahasiswa program studi pendidikan IPA STKIP Citra Bakti dalam 8 kali pertemuan. 
Pertemuan pertama dan kedua dilaksanakan pada tanggal 8 November 2019. Pelaksanaan pendampingan diawali dengan pemberian tes kepada seluruh peserta. Setelah mendapat hasil pretest, para siswa kemudian dibagi dalam beberapa kelompok berdasarkan hasil pretest dengan tingkat kemampuan yang heterogen. Masing-masing kelompok didampingi oleh seorang mahasiswa. Proses selanjutnya adalah pemberian materi fisika oleh dosen sebagai bentuk penguatan agar siswa dapat mengingat kembali materi-materi IPA-fisika yang telah dipelajari.

Pertemuan ketiga dan keempat dilaksanakan pada tanggal 15 November 2019. Pelaksanaan kegiatan berupa penyelesaian masalah dan soal-soal yang disajikan oleh pendamping. Siswa-siswi diberikan kesempatan untuk menyelesaikan soal-soal fisika menggunakan cara yang biasa digunakan. Mahasiswa mendampingi proses belajar masingmasing kelompok dengan dibantu oleh dosen. Melalui tahapan belajar ini, pendamping mendapatkan gambaran mengenai pemahaman siswa-siswi terhadap konsep dan persamaan dalam penyelesaian masalah fisika. Sebagian besar siswa membutuhkan waktu lebih dari 5 menit untuk menyelesaikan satu soal fisika. Selain karena kurang memahami konsep dan persamaan yang harus digunakan, para siswa juga menggunakan proses yang panjang dalam penyelesaian soal tersebut.

Pertemuan kelima dan keenam dilaksanakan pada tanggal 22 November 2019. Pelaksanaan kegiatan masuk pada tahap pendampingan belajar menggunakan smart solution dengan real world problem. Dosen dengan didampingi mahasiswa memberikan gambaran kepada siswa-siswi mengenai cara penyelesaian soal-soal menggunakan smart solution dengan real world problem. Setelah itu, siswa-siswi diberikan kesempatan untuk menggunakan metode tersebut melalui proses diskusi dengan anggota kelompok masingmasing. Hal ini dimaksudkan agar pemahaman siswa-siswi dalam menggunakan metode tersebut semakin baik.

Pertemuan ketujuh dan kedelapan dilaksanakan pada tanggal 29 November 2019. Pada pertemuan ketujuh, siswa-siwi diberikan waktu untuk menggunakan metode smart solution dengan real world problem dalam penyelesaian soal-soal fisika secara mandiri. Selanjtunya pada pertemuan kedelapan, diberikan posttest untuk penyelesaian soal dan masalah-masalah fisika dengan harapan bentuk penyelesaian yang diberikan telah menggunakan metode smart solution.

Kegiatan pendampingan ini diikuti oleh 67 siswa. Soal pretest dan posttest yang diberikan adalah soal yang sama. Indikator penyelesaian soal tersebut selain nilai juga pada waktu yang digunakan siswa untuk menyelesaikan soal. Terdapat 30 butir soal dengan waktu penyelesaian yang diberikan adalah 60 menit. Penyelesaian soal menggunakan metode smart solution dengan real world problem diharapkan dapat membuat siswa lebih cepat mengerjakan soal dengan cara yang tepat. 
Selain itu pula, dilakukan wawancara kepada beberapa orang siswa SMP peserta kegiatan pengabdian ini mengenai pengaruh metode smart solution dengan real world problem terhadap proses pemecahan masalah fisika dan minat siswa terhadap pembelajaran fisika. Berikut adalah hasil kegiatan pengabdian yang diukur melalui hasil pretest dan posttest siswa setelah mengikuti kegiatan pendampingan belajar fisika, disajikan dalam Gambar 1.

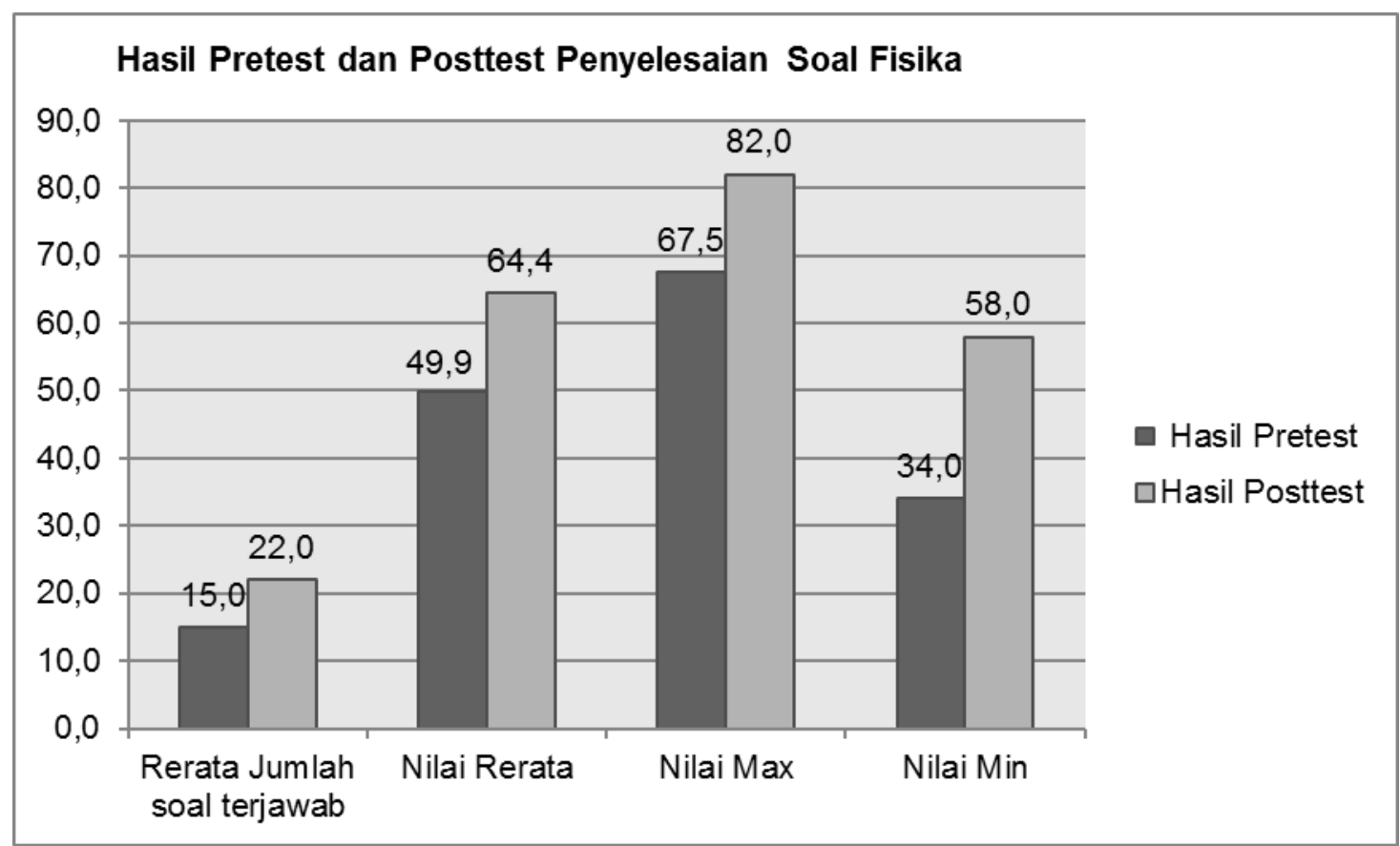

Gambar 1. Hasil pretest dan posttest siswa dalam penyelesaian soal fisika

Gambar 1 di atas memperlihatkan bahwa dalam waktu 60 menit, pada pretest rerata jumlah soal yang dapat dikerjakan siswa sebanyak 15 dengan nilai rata-rata 49.9; nilai maksimum 67.5 dan nilai minimum 34.0. Sementara itu, pada posttest rerata jumlah soal yang dapat dikerjakan siswa dalam wakyu 60 menit sebanyak 22 dengan nilai rata-rata 64.4; nilai maksimum 82.0; dan nilai minimum 58.0.

\section{Pembahasan}

Kegiatan pendampingan belajar fisika menggunakan metode smart solution dengan real world problem yang dilakukan oleh dosen dan mahasiswa STKIP Citra Bakti program studi pendidikan IPA memberikan hasil yang positif. Hal ini dapat dilihat dari grafik yang ditunjukkan pada Gambar 1 di atas. Hasil posttest menunjukkan pengaruh yang positif, di mana nilai-nilai siswa mengalami peningkatan dan waktu penyelesaian soal untuk jenis dan jumlah yang sama dengan tes awal lebih sedikit. Beberapa siswa memang masih mengalami kebingungan dan tetap menggunakan cara konvensional namun alur berpikirnya telah menunjukkan adanya pemahaman yang lebih baik terhadap konsep fisika. 
Hasil yang dicapai dalam kegiatan pendampingan belajar fisika bagi siswa kelas VIII SMPN 4 Golewa dan SMP Citra Bakti dapat diuraikan sebagai berikut:

1. Para siswa menjadi lebih mudah mengingat dan menyelesaikan soal fisika menggunakan rumus-rumus yang dikembangkan dalam smart solution. Pengalaman nyata siswa dalam kehidupan sehari-hari yang disajikan dalam pembelajaran menjadi stimulus yang mendorong kreativitas siswa dalam memecahkan soal-soal. Hal ini memberikan pengaruh positif dalam meningkatkan pemahaman siswa mempelajari fisika.

2. Para siswa menjadi lebih bersemangat dan antusias dalam mempelajari fisika. Proses pembelajaran yang dibangun dengan melihat keterkaitan antara kehidupan siswa dan materi yang dipelajari, menumbuhkan rasa keingintahuan siswa. Hal ini memberikan dampak yang positif terhadap ketertarikan para siswa dalam belajar fisika yang pada awalnya dianggap sebagai mata pelajaran yang sulit.

Proses belajar fisika menggunakan metode smart solution dengan real world problem pada dasarnya menekankan pada kegiatan belajar yang memberikan kesempatan kepada siswa untuk memperoleh pengetahuan dan beragam keterampilan dalam memecahkan masalah. Keterampilan yang dimaksud adalah kemampuan pemecahan masalah dengan beragam cara yang mendorong kreativitas seperti membuat sketsa, menentukan informasi yang relevan dengan masalah, dan memutuskan cara yang dapat digunakan untuk menyelesaikan masalah tersebut. Siswa juga belajar memecahkan masalah berbasis pada solusi cerdas menggunakan rumus atau cara yang mudah diterapkan dan diingat. Melalui metode ini, siswa belajar untuk tidak hanya sekedar dapat mengingat materi pelajaran, akan tetapi menguasai dan memahaminya secara penuh, sebab siswa membangun sendiri pengetahuannya melalui pengalaman nyata dalam kehidupan sehari-harinya. Proses belajar menjadi lebih bermakna.

Hasil posttest menunjukkan metode smart solution dengan real world problem dapat membantu siswa dalam menyelesaikan soal-soal dengan cepat dan tepat berdasarkan pengalaman nyata sehari-hari serta meningkatkan pemahaman siswa terhadap materi fisika.

Selain itu, dilakukan pula wawancara dengan beberapa orang peserta kegiatan ini. Wawancara dimaksudkan untuk mengetahui bagaimana respon serta kesan para peserta dalam mempelajari fisika dan menyelesaikan soal-soalnya menggunakan metode smart solution dengan real world problem yang diajarkan oleh para dosen dan mahasiswa STKIP Citra Bakti. Hasil wawancara menunjukkan respon yang positif terhadap penggunaan metode smart solution dengan real world problem dalam proses pemecahan masalah fisika. Soal-soal fisika dapat diselesaikan dengan cara yang lebih cepat dan rumusnya lebih mudah diingat. Selain itu, para peserta menunjukkan keantusiasan yang besar dalam mempelajari fisika. "Fisika ternyata dapat dipelajari dengan mudah karena banyak hal dalam kehidupan 
sehari-hari dapat dijelaskan secara fisika. Fisika ternyata mata pelajaran yang menarik. Terima kasih bapak/ibu dosen dan kakak-kakak".

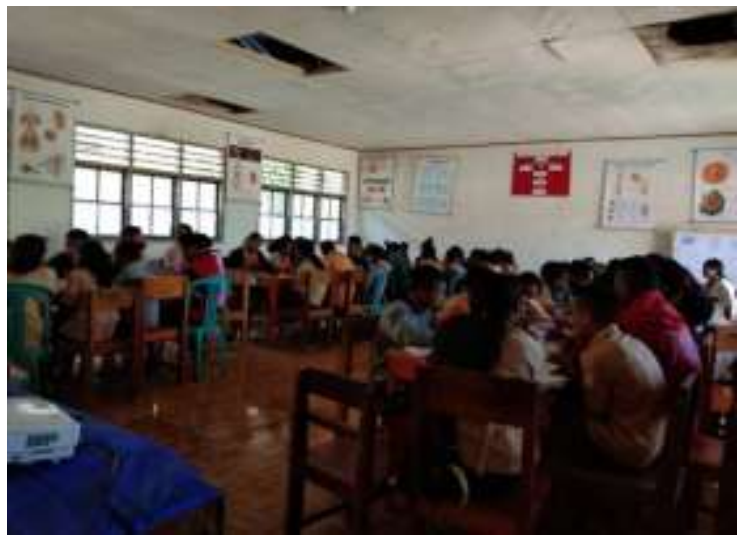

Gambar 2. Kegiatan belajar fisika

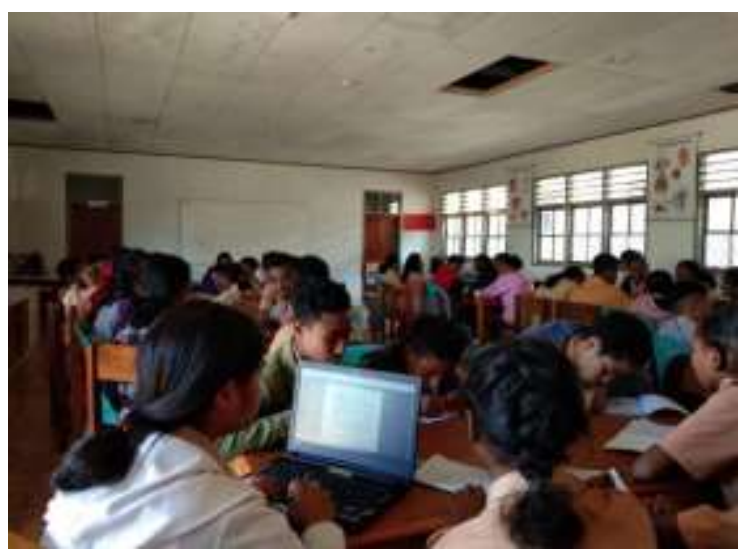

Gambar 4. Pendampingan belajar oleh mahasiswa

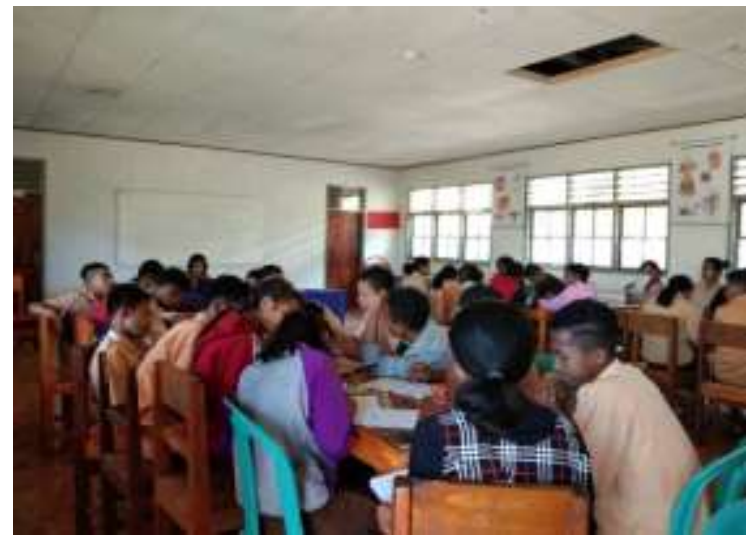

Gambar 3. Pendampingn belajar oleh mahasiswa

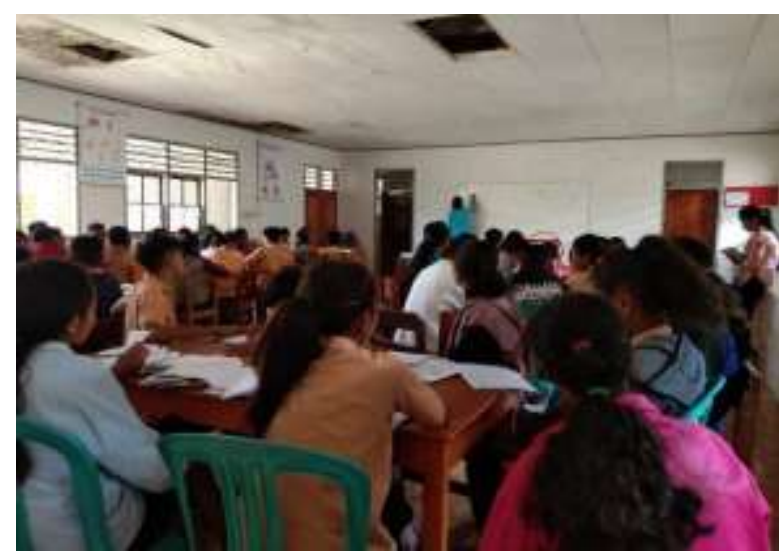

Gambar 5. Pendampingan belajar oleh dosen

\section{KESIMPULAN}

Berdasarkan serangkaian proses dalam kegiatan pendampingan belajar fisika menggunakan metode smart solution dengan real world problem maka dapat ditarik kesimpulan; 1) Metode yang digunakan dalam pengabdian ini dapat meningkatkan pemahaman siswa dalam penyelesaian soal-soal fisika melalui langkah-langkah cepat dan mudah berdasarkan pengalaman nyata dalam kehidupan sehari-hari. 2) Para siswa mulai menunjukkan respon yang positif dengan keantusiasan yang besar dalam pembelajaran fisika yang selalu dianggap sulit. Melalui kegiatan ini, hasil yang diperoleh kiranya dapat pula memberikan gambaran bagi pihak sekolah untuk mengetahui sejauh mana tingkat pemahaman dan pengetahuan siswa dalam mempelajari materi fisika yang dapat digunakan sebagai refleksi untuk memberikan tindak lanjut yang tepat. 


\section{DAFTAR PUSTAKA}

Depdiknas. (2006). Peraturan Menteri Pendidikan Nasional Republik Indonesia Nomor 22 Tahun 2006 tentang Standar Isi.

Docktor, J. L., \& Mestre, J. P. (2014). Synthesis of discipline-based education research in physics. Physical Review Special Topics - Physics Education Research, 10(2), 1-58. https://doi.org/10.1103/PhysRevSTPER.10.020119

Hussain, A., \& Shakoor, A. (2011). Physics teaching methods: scientific inquiry vs traditional lecture. International Journal of Humanities and Social Science, 1(19), 269-276.

Johan, H. (2012). Pengaruh search, solve, create, and share (sscs) problem solving untuk meningkatkan kemampuan mahasiswa dalam merumuskan dan memilih kriteria pemecahan masalah pada konsep listrik dinamis. Jurnal Exacta, X(2), 140-142.

Kua, M. Y. (2018). Kepraktisan penerapan model pembelajaran real world problem solving dalam pembelajaran fisika di sekolah menengah atas. Jurnal IImiah Pendidikan Citra Bakti, 5(1), 24-34.

Kua, M. Y., Ulviah, L., Sawu, A. M., \& Ngole, M. (2015). Analysis of the speed of a moving object through the application of videopad to teach mechanical concepts based on a real world problem. Proceeding of International Seminar on Science Education Yogyakarta State University, October 31 St 2015, 255-266.

Nchunga, A., \& Kira, E. (2016). Inclusion of real life materials in teaching physics concepts: students' experiences and perceptions. International Journal of English and Education, $5(1), 1-14$.

Warimun, E. (2012). Penerapan Model pembelajaran problem solving fisika pada pembelajaran topik optika pada mahasiswa pendidikan fisika. Exacta, X(2), 111-114. 